\title{
Sequential Michael addition/biscyclization reactions leading to the formation of highly substituted polycyclic substrates: some preliminary studies
}

\author{
Cyril Bressy, Didier Bruyère, Didier Bouyssi, and Geneviève Balme*
}

Laboratoire de Chimie Organique 1, CNRS UMR 5622, Université Claude Bernard, Lyon 1, CPE. 43, Bd du 11 Novembre 1918, 69622 Villeurbanne

E-mail: balme@univ-lyon1.fr

\begin{abstract}
Dedicated to Professor Moreno-Mañas on the occasion of his $60^{\text {th }}$ birthday with regards and best wishes

(received 06 Feb 02; accepted 27 Mar 02; published on the web 04 Apr 02)
\end{abstract}

\begin{abstract}
An intermolecular Michael addition reaction of a malonate or malononitrile to unsaturated carbonyl substrates Z2a, E2a and E2b followed by a palladium-mediated biscyclization reaction led to the formation of highly functionalised tricyclic compounds with, in general, a high level of selectivity. A preliminary study on the transformation of one of these resulting substrates into a tetracyclic compound is also presented.
\end{abstract}

Keywords: Intermolecular Michael additions, palladium, biscyclization, polycyclics

\section{Introduction}

In recent years, transition metal-mediated tandem or cascade reactions have become a powerful method for the one-step synthesis of various carbo- and heterocyclic systems. Many groups have made important contributions to this area and the scope and limitation of such reactions have been the subject of recent reviews. ${ }^{1}$ As a part of our ongoing effort to expand the synthetic utility of a new palladium-mediated cyclization reaction developed in our group, ${ }^{2}$ we recently reported efficient strategies for the construction of tricyclic structures. ${ }^{3}$ In particular, we have demonstrated that the palladium-catalysed cyclization of linear compounds of type $\mathbf{1}$ ( $\mathrm{Z}$ or $\mathrm{E}$ ) proceeds with complete retention of the stereochemistry in a stereocontrolled mode since it involves attack of the carbon nucleophile onto the double bond electrophilically activated by the organopalladium species. Moreover, the regiochemistry of the cyclisation (5 exo versus 6 endo) can be controlled by the steric bulk of the nucleophile part (Scheme 1). ${ }^{4}$ 


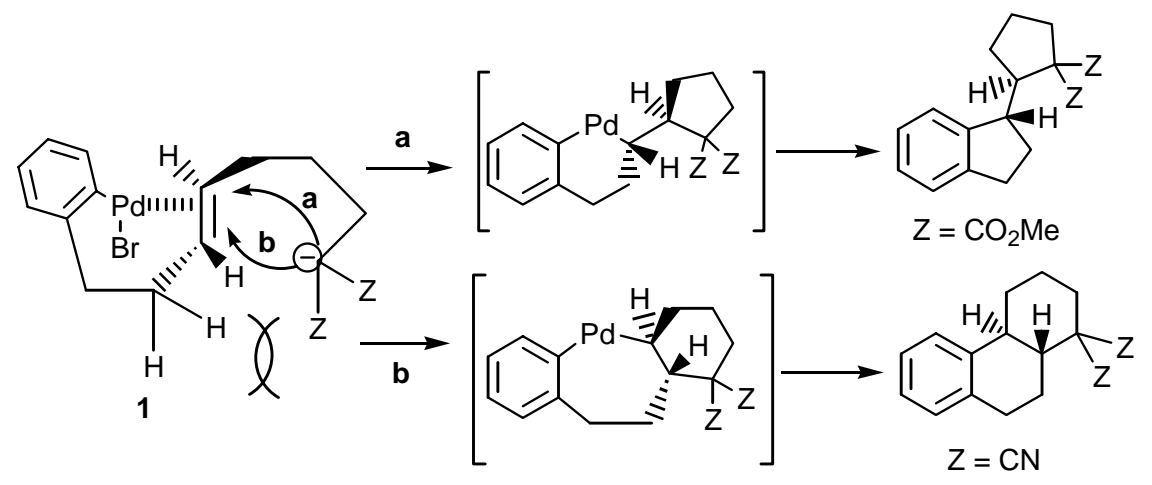

\section{Scheme 1}

We now report further progress based on the use of an intermolecular Michael addition reaction coupled with this palladium mediated biscyclization reaction. The motivation of this study emanates from the view that this would permit suitable functionalisation of ring $\mathrm{C}$ and thereby provide potential intermediates for the synthesis of various tetracyclic compounds by way of several synthetic transformations (Scheme 2). ${ }^{5}$ Another challenging aspect of this tandem reaction lies in the level of selectivity on this palladium biscyclization reaction with respect to the relative configuration of the three newly formed chiral centers.

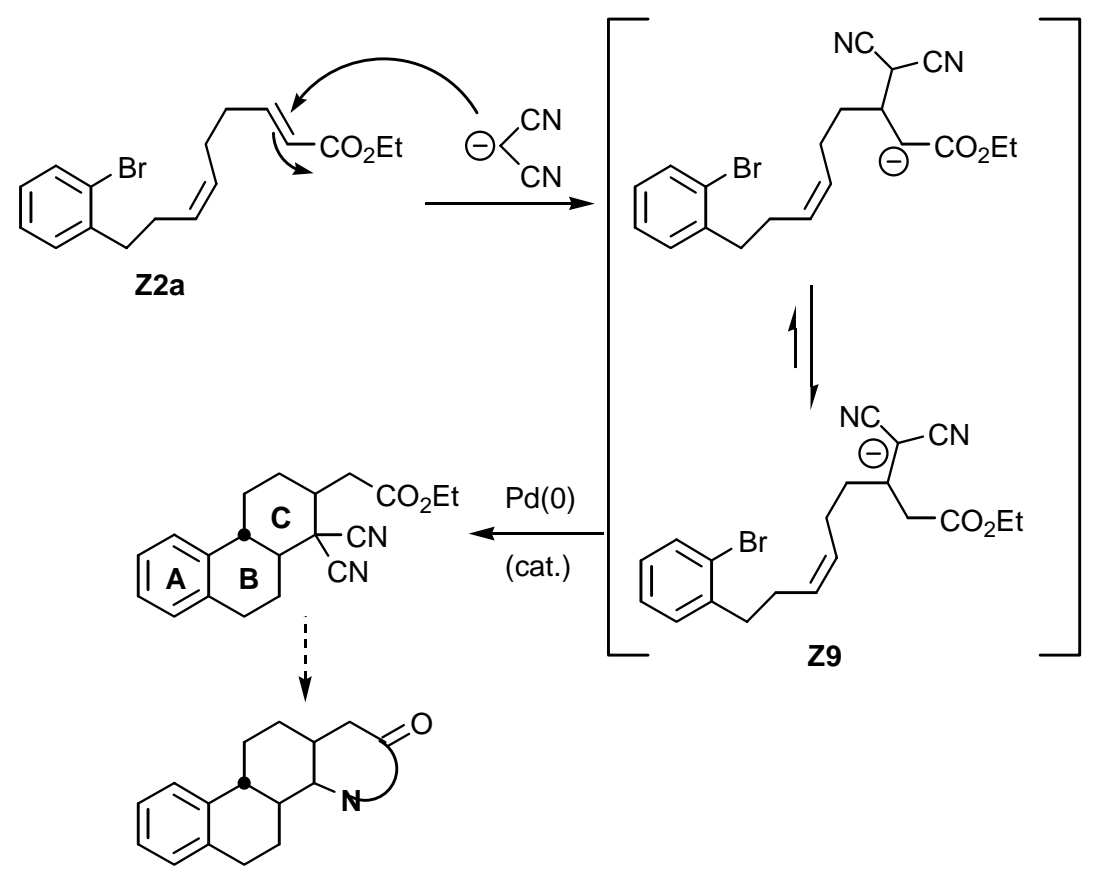

\section{Scheme 2}

\section{Results and Discussion}

In order to test the feasibility of this Michael addition-biscyclization reaction, we needed access to $\alpha$ - $\beta$-unsaturated carbonyl compounds E2a and Z2a. They were readily prepared from the known aldehyde $3^{6}$ as summarized in Schemes 3 and 4. 
The synthesis of E2a began with the addition of vinylmagnesium bromide to $\mathbf{3}$ which provided the allylic alcohol 4 . To effect the Claisen rearrangement, this alcohol was placed in refluxing butyl vinyl ether, in the presence of mercuric acetate. ${ }^{7}$ To complete the sequence, the resulting aldehyde 5 was treated with carbomethoxymethylene triphenylphosphorane to afford E2a in $81 \%$ yield. In order to introduce another functional group for further transformation, we also prepared the unsaturated ketone E2b (82\%) using a mild olefination procedure, conventional methods giving poor results.

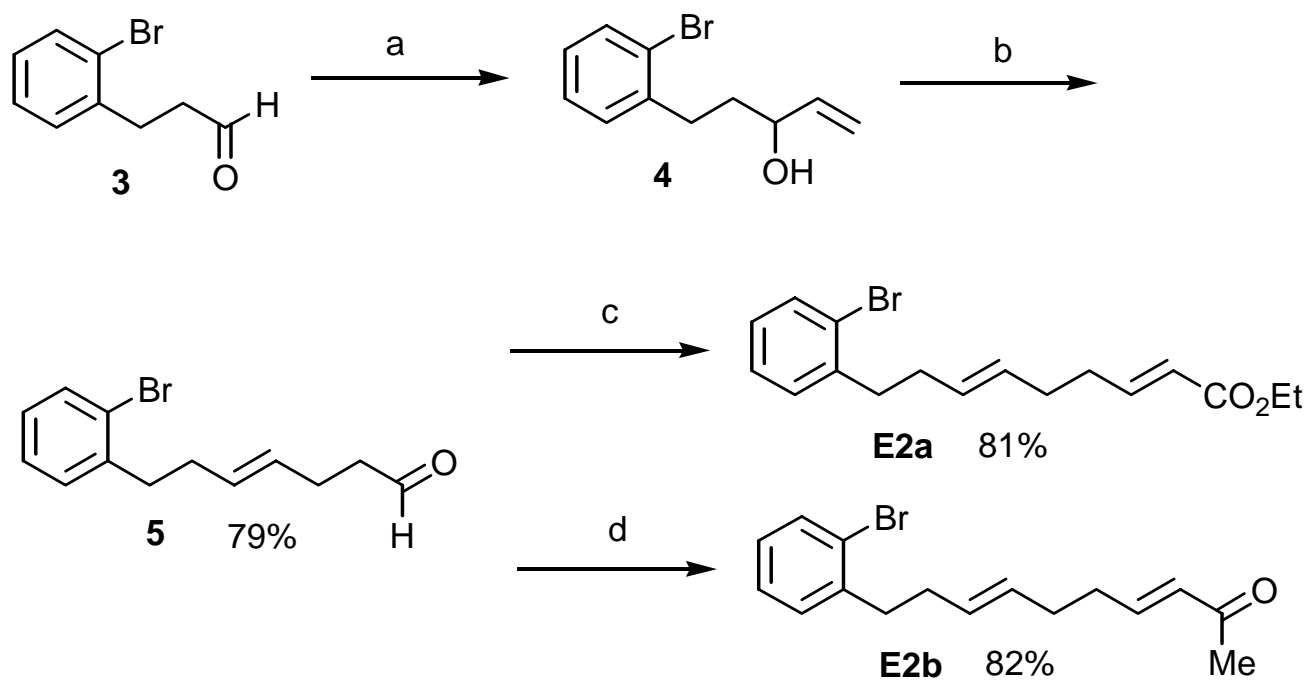

Scheme 3. (a) vinyl magnesium bromide, THF, $0^{\circ} \mathrm{C}$. (b) butyl vinyl ether, $\mathrm{Hg}(\mathrm{OAc})_{2}, \Delta$. (c) $\mathrm{NaH}$, THF, $0^{\circ} \mathrm{C},(\mathrm{EtO})_{2} \mathrm{P}(\mathrm{O}) \mathrm{CH}_{2} \mathrm{CO}_{2}$ Et. (d) $(\mathrm{MeO})_{2} \mathrm{P}(\mathrm{O}) \mathrm{CH}_{2} \mathrm{COMe}$, DIPEA, LiCl, $\mathrm{CH}_{3} \mathrm{CN}$.

The synthesis of the isomerically pure Z2a was realized through a three-step sequence. Wittig olefination of aldehyde 3 with the phosphorane derived from 4-bromobutyronitrile ${ }^{8}$ proceeded smoothly at $0^{\circ} \mathrm{C}$ to provide olefin 6 in $90 \%$ yield. The nitrile function was then converted to the aldehyde 7 by reduction with diisobutylaluminium hydride. Introduction of the conjugated carboethoxy group was also carried out by a Wittig reaction.

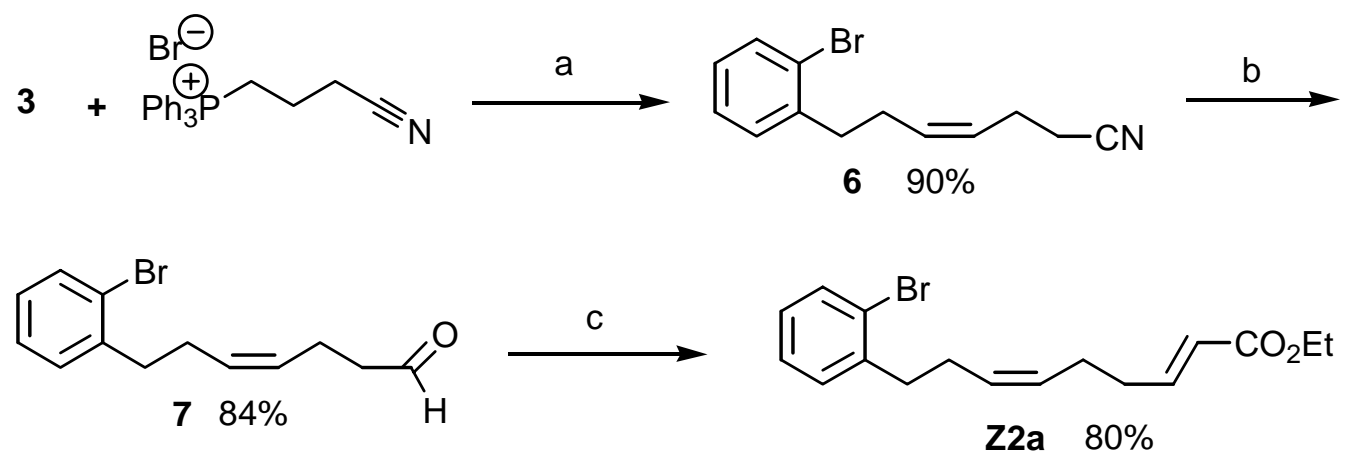

Scheme 4. (a) KHMDS, THF, $0^{\circ} \mathrm{C}$; (b) DIBAL-H, $\mathrm{Et}_{2} \mathrm{O},-78^{\circ} \mathrm{C}$; (c) $\mathrm{NaH}, \mathrm{THF},{ }^{\circ} \mathrm{C}$, $(\mathrm{EtO})_{2} \mathrm{P}(\mathrm{O}) \mathrm{CH}_{2} \mathrm{CO}_{2} \mathrm{Et}$. 
We initially attempted the sequential Michael addition / biscyclization reaction via a one pot procedure. We envisaged that Michael addition of active methylene compounds such as malonate and malononitrile to the $\alpha-\beta$-unsaturated carbonyl compound such as Z2a would lead to the expected stabilised anionic intermediate $\mathbf{Z 9}$ by proton transfer. Addition of an appropriate palladium( 0 ) complex to the reaction mixture would allow the biscyclization process to take place according to Scheme 2. ${ }^{10}$

First of all, we studied the reaction of Z2a with the malonic enolate prepared from diethyl malonate and potassium hydride in THF as solvent. Although Michael addition of methylmalonate was nearly complete, as observed by GC, this solvent was not suitable for the biscyclization reaction. After addition of the palladium catalyst, no reaction occurred even after prolonged times at reflux of the solvent. Attempted modification of this standard method was unsuccessful in spite of variations of the solvent, the base, the temperature, the nature of the palladium catalyst and of the nucleophile (malononitrile in place of diethyl malonate). Consequently, we decided to overcome these problems by studying first the conjugate addition of active methylene compounds and secondly the biscyclization of the resulting adducts.

Michael addition of the sodium salt of diethylmalonate to Z2a in refluxing THF containing a catalytic amount of 18-crown-6 afforded adduct $\mathbf{Z 8}$ in $77 \%$ yield. Addition of malononitrile to the same substrate and to the trans analogue E2a required the use of -tBuOK as base instead of $\mathrm{NaH}$, adducts Z9 and E10 were then obtained in respectively $84 \%$ and $80 \%$ yield. When these conditions were used for addition of malononitrile to the $\alpha, \beta$-unsaturated ketone $\mathbf{E} 2 \mathbf{b}$, the yield of the adduct E11 was very low (25\%). However, by employing the ruthenium(II) catalyzed conditions developed by Echavarren, the yield of E11 could be improved to $63 \% .{ }^{11}$ A significant amount $(23 \%)$ of the starting material was also recovered (Scheme 5)

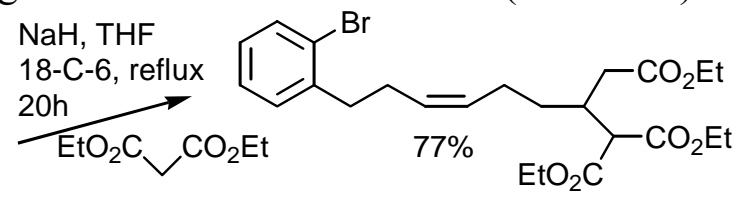

$\mathbf{Z 8}$

$\mathrm{Z2a}$

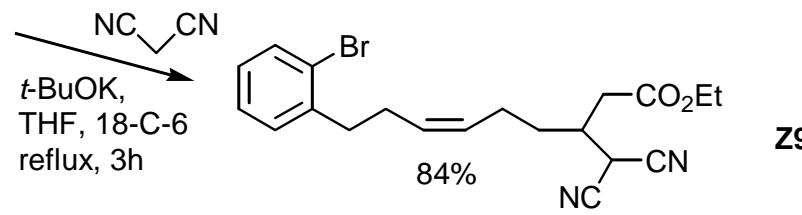

Z9

E2a
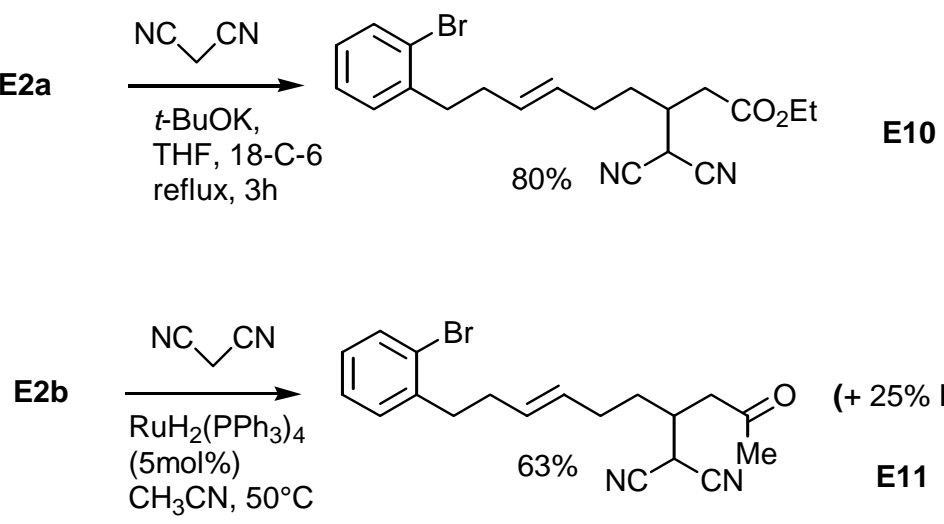

(+ 25\% E2b)

Scheme 5 
We next examined the palladium mediated biscyclization of these four cyclization precursors, aryl bromides Z8, Z9, E10 and E11. They were subjected to the conditions that had been determined optimum for the cyclization of the linear homologous substrates. ${ }^{4}$ The reaction was carried out by heating of a substrate in NMP at $60^{\circ} \mathrm{C}$ in the presence of $5 \%$ mole $\mathrm{Pd}(\mathrm{dppe})$, 1.1 equivalent of $\mathrm{KH}$ and 0.2 equivalent of 18-crown-6. Under these conditions, the less sterically demanding nucleophile $\mathbf{Z 9}$ underwent a clean regiospecific cyclization to afford a 2:1 mixture of $\mathrm{C}_{2}$ epimeric perhydrophenanthrene substrates 12a and 12b in 73\% total yield without formation of 5-exo-trig cyclization products. The structure of the cyclization products have been elucidated by analysis of the ${ }^{1} \mathrm{H}$ and ${ }^{13} \mathrm{C}$ NMR spectra in comparison with those of the linear analogues having no $\mathrm{CH}_{2} \mathrm{CO}_{2} \mathrm{Et}$ side chain whose structure had been confirmed by X-ray crystallography. ${ }^{4}$ As anticipated, a high degree of stereocontrol was observed during the cyclisation. The geometry of the newly formed ring junction is cis, this being in accord with the reaction mechanism proposed above. The major isomer could be isolated from the mixture by careful medium pressure liquid chromatography. Its structure has been deduced on the basis of NMR spectroscopic data. Indeed, 2D homo- and heteronuclear experiments allowed for identification of most of the hydrogens and carbons and in particular the small ${ }^{1} \mathrm{H}$ NMR coupling $\left({ }^{3} \mathrm{~J}=4.6 \mathrm{~Hz}\right)$ observed between the two adjacent ring methine protons $\left(\mathrm{H}_{5}\right.$ and $\left.\mathrm{H}_{14}\right)$ confirmed the cis fused configuration. In the NOESY experiments, the presence of a cross peak between the two vicinal methine protons confirmed the cis ring fusion. The lack of signals between these two protons and the third methine $\mathrm{C}_{2}$ proton and the presence of a cross peak between $\mathrm{H}_{2}$ and one proton $\mathrm{H}_{13}$ indicated that the side chain $\mathrm{CH}_{2} \mathrm{CO}_{2} \mathrm{Et}$ and the two vicinal methine protons were on the same face of the molecule. (Scheme 6)

The palladium-catalysed cyclization of the bulkier nucleophile Z8, under the same conditions led to the exclusive formation of cyclopentanic compounds 13a and 13b with no selectivity at the $\mathrm{C}_{2}$ center (1:1 mixture according to GC) (Scheme 6). The stereostructural assignments for these tricyclic compounds were based on the close resemblance of their ${ }^{1} \mathrm{H}$ and ${ }^{13} \mathrm{C}$ NMR to those of the linear homologue having no side chain. ${ }^{4}$

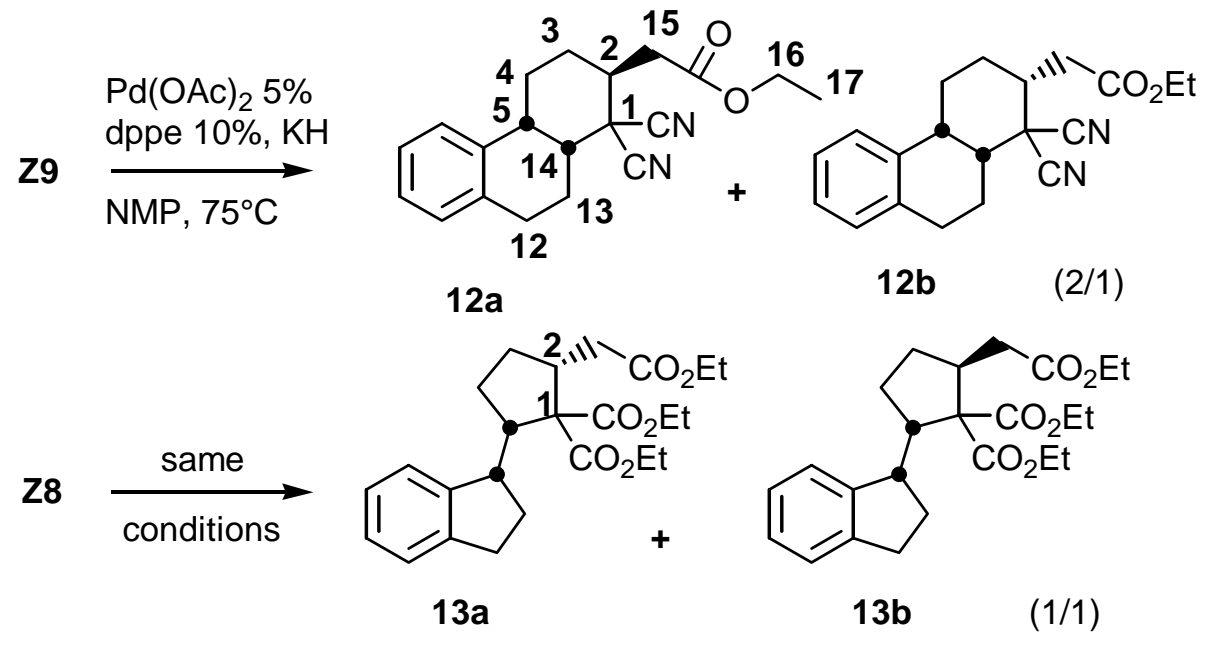

\section{Scheme 6}


Under identical reaction conditions $\left(60^{\circ} \mathrm{C}, 3 \mathrm{~h}\right)$ the cyclization of E10 resulted in the formation of the tricyclic compound $\mathbf{1 4}$ as a single isomer as indicated by $\mathrm{GC},{ }^{1} \mathrm{H}$ and ${ }^{13} \mathrm{C} \mathrm{NMR}$. The structural and stereochemical assignments for this isomer were made on the basis of the HSQC, TOCSY and NOESY spectra. In particular, in the NOESY spectra, the presence of a cross peak between the two methine protons on both side of the carbon bearing the nitrile group allowed to assign the stereochemistry as shown in Scheme 7.

It is noteworthy that the palladium-mediated cyclization reaction of linear alkenes (having no $\mathrm{CH}_{2} \mathrm{CO}_{2} \mathrm{Et}$ side chain) bearing a malononitrile were generally considerably slower (60h) than that of the corresponding malonates $(5 \mathrm{~h}){ }^{4,12}$ Concerning the cyclization of $\mathbf{Z 9}$ and E10, we observed a significantly faster biscyclisation of these two compounds compared to the linear dinitrile substrates (3.5h). This can be interpreted as a consequence of the Thorpe-Ingold effect.

When the same cyclisation reaction conditions were applied to the ketone E11, an intense degradation was observed and several by-products were formed along with the expected tricyclic compound 15 which could be isolated in only $14 \%$. These failures seemed due to the presence of the keto group since performing this reaction on the corresponding protected ketone was successful and afforded a 3:1 mixture of $\mathrm{C}_{2}$ epimeric compounds in $89 \%$ combined yield. The major isomer could be isolated by recrystallization from diethyl ether and mild acidic treatment liberated the ketone. The assigned structure of the resulting major isomer 15a has been elucidated from its NMR spectrum and by analogy to 14a.

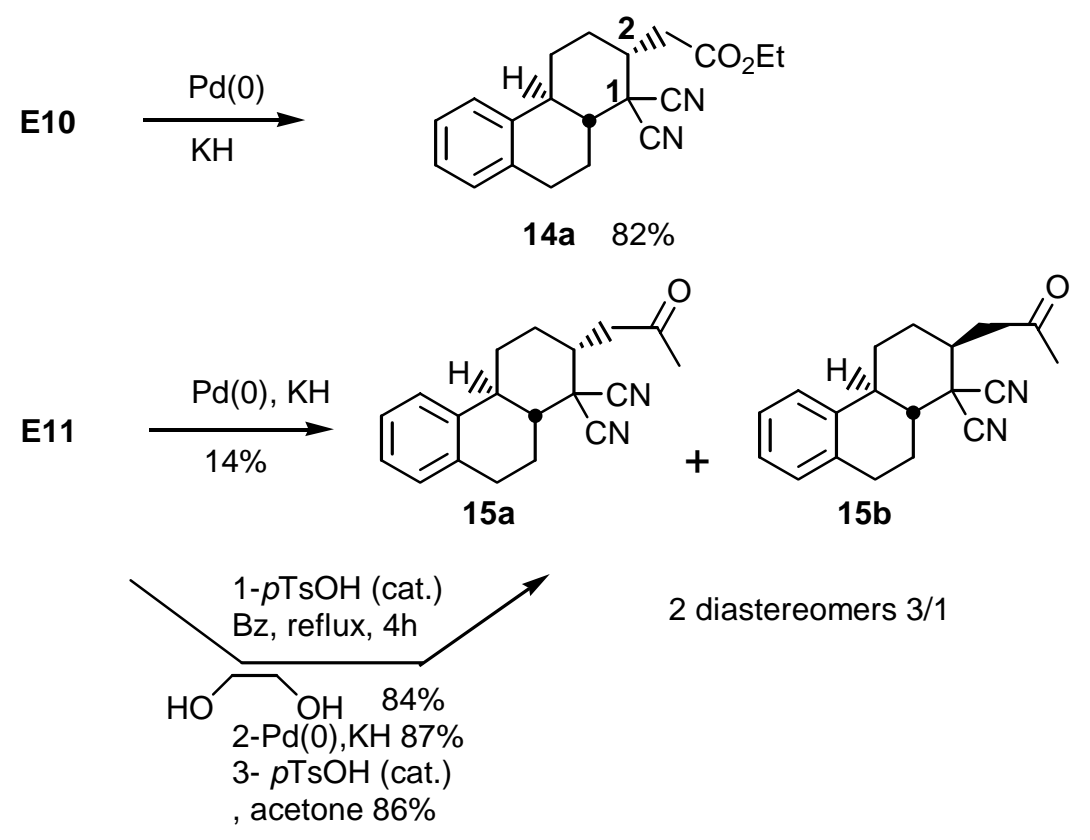

$12 a$

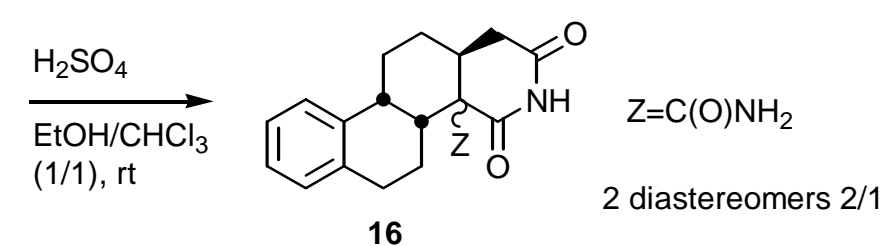

\section{Scheme 7}


As mentioned in the introduction, the three highly functionalized perhydrophenanthrenes obtained in these two-step procedure may undergo further transformations to give tetracyclic substrates. As an example, we decided to prepare a tetracyclic lactam from the tricyclic nitrile ester 12a. Therefore, 12a was treated with concentrated $\mathrm{H}_{2} \mathrm{SO}_{4}$ in absolute EtOH to provide the target compound as an inseparable 2:1 mixture of diastereomers 16 in $66 \%$ combined yield. The assigned structure of these resulting tetracyclic products were corroborated by their IR, ${ }^{1} \mathrm{H}$ and ${ }^{13} \mathrm{C}$ NMR as well as their CI mass spectra.

Further extension of the scope of this Michael-addition/biscyclization reaction will be reported in due course.

\section{Experimental Section}

General Prpcedures. All reactions were carried out under a nitrogen atmosphere using standard syringe, cannula and septa techniques. All reactions were monitored by thin layer chromatography carried out on aluminium plates precoated with silica gel $60 \mathrm{~F}_{254}$ (Merck) or by gas chromatography on a DB 1 capillary column $30 \mathrm{~m}$. Column chromatographies were performed on silica gel SI 60 (40-60 $\mu$, MERCK). Melting points (uncorrected) were determined on a Büchi Melting Point 510. IR spectra were recorded on a Perkin-Elmer 337 instrument. Nuclear Magnetic Resonance spectra were obtained on a Brucker ALS 300 spectrometer $\left({ }^{1} \mathrm{H}\right.$ : $300 \mathrm{MHz}$ or ${ }^{13} \mathrm{C}: 75 \mathrm{MHz}$ ) using TMS as an internal standard. Chemical shifts were expressed in ppm downfield from TMS and coupling constants $(\mathrm{J})$ in Hertz. Microanalysis were performed by Service Central d'Analyse du CNRS, Solaize, France. THF was distilled from Na/benzophenone, $\mathrm{N}$-methylpyrrolidone (NMP) and DMSO (dimethylsulfoxide) were distilled from $\mathrm{CaH}_{2}, \mathrm{DMF}$ was distilled from $\mathrm{P}_{2} \mathrm{O}_{5}$ and $\mathrm{Et}_{2} \mathrm{O}$ was distilled from $\mathrm{LAH}$ prior to use.

Preparation of 4. Vinyl magnesium bromide $1 \mathrm{M}$ in THF (11.1 $\mathrm{mL}, 11.1 \mathrm{mmol})$ was added dropwise at $-30^{\circ} \mathrm{C}$ to a solution of aldehyde $3(1.57 \mathrm{~g}, 7.37 \mathrm{mmol})$ in $20 \mathrm{~mL}$ of THF. At the end of the addition, the solution was warmed up to room temperature and stirred for two hours. The mixture was quenched with saturated $\mathrm{NH}_{4} \mathrm{Cl}$ solution and extracted with $\mathrm{Et}_{2} \mathrm{O}$. After drying under $\mathrm{MgSO}_{4}$ and evaporation under vacuum, the crude oil was purified by flash chromatography $\left(\mathrm{PE} / \mathrm{Et}_{2} \mathrm{O} 7: 3\right)$ to afford allyl alcohol 4 as an oil in 90\% yield. ${ }^{1} \mathrm{H}-\mathrm{NMR} \delta 1.75$ $(1 \mathrm{H}, \mathrm{s}), 1.75(\mathrm{H}, \mathrm{m}), 1.83-1.91(2 \mathrm{H}, \mathrm{m}), 2.77-2.95(2 \mathrm{H}, \mathrm{m}), 4.18-4.2(1 \mathrm{H}, \mathrm{m}), 5.15-5.33(2 \mathrm{H}, \mathrm{m})$, $5.95(1 \mathrm{H}$, ddd, $J=17.2,10.4,6), 7.04-7.10(1 \mathrm{H}, \mathrm{m}), 7.22-7.28(2 \mathrm{H}, \mathrm{m}), 7.55(1 \mathrm{H}, \mathrm{d}, J=7.8)$; ${ }^{13} \mathrm{C}-\mathrm{NMR} \delta 32.2,37.1,72.6,115.7,124.6,127.6,127.8,130.6,133.0,141.0,141.3$; IR v 3400, 3060, 2920, 2860, 1640, 1570, 1470, 1020, 990, 920, 900;

Preparation of 5. To a solution of allyl alcohol 4 (1.34 g, $5.56 \mathrm{mmol})$, in $14 \mathrm{~mL}$ of butylvinyl ether was added mercuric acetate $(1.72 \mathrm{~g}, 5.42 \mathrm{mmol})$. The resulting mixture was stirred at reflux for $18 \mathrm{~h}$. The reaction was quenched with sodium carbonate $(20 \mathrm{~mL})$ and extracted with $\mathrm{CH}_{2} \mathrm{Cl}_{2}$ $(2 \times 30 \mathrm{~mL})$. The combined organics were washed with brine and dried over $\mathrm{MgSO}_{4}$. Purification by flash chromatography $\left(\mathrm{PE} / \mathrm{Et}_{2} \mathrm{O} 9: 1\right)$ furnished the aldehyde 5 as an oil in $79 \%$ yield. ${ }^{1} \mathrm{H}-$ NMR $\delta 2.07-2.40(\mathrm{~m}, 4 \mathrm{H}), 2.46-2.51(2 \mathrm{H}, \mathrm{m}), 2.78(2 \mathrm{H}, \mathrm{dd}, J=6.5,8.7), 5.39-5.58(2 \mathrm{H}, \mathrm{m})$, 
7.02-7.08 $(1 \mathrm{H}, \mathrm{m}), 7.16-7.27(2 \mathrm{H}, \mathrm{m}), 7.52(1 \mathrm{H}, \mathrm{dd}, J=1.1,8), 9.75(1 \mathrm{H}, \mathrm{s}) ;{ }^{13} \mathrm{C}-\mathrm{NMR} \delta 25.5$, 33.0, 36.5, 43.8, 124.8, 127.7, 128.0, 129.2, 130.9, 133.1, 141.4, 202.7; IR v 3040, 2920, 2720, $1720,1040,965,750$.

Preparation of E2a. Same procedure as for Z2a: scale $1.26 \mathrm{~g}$, $4.72 \mathrm{mmol}$ of 5. Purification by flash chromatography ( $\left.\mathrm{PE} / \mathrm{Et}_{2} \mathrm{O} 9: 1\right)$ led to the ester E2a as an oil in $81 \%$ yield. ${ }^{1} \mathrm{H}-\mathrm{NMR} \delta 1.31$ $(3 \mathrm{H}, \mathrm{t}, J=7.2), 2.14-2.36(\mathrm{H}, \mathrm{m}), 2.8(2 \mathrm{H}, \mathrm{t}, J=7.5), 4.20(\mathrm{q}, 2 \mathrm{H}, J=7.2), 5.39-5.58(2 \mathrm{H}, \mathrm{m})$, $5.83(1 \mathrm{H}, \mathrm{d}, J=15.6), 6.91-7.09(2 \mathrm{H}, \mathrm{m}), 7.19-7.28(2 \mathrm{H}, \mathrm{m}), 7.54(1 \mathrm{H}, \mathrm{d}, J=8.3) ;{ }^{13} \mathrm{C}-\mathrm{NMR} \delta$ $14.7,31.3,32.5,33.1,36.6,60.6,122.0,124.9,127.7,127.9,129.9,130.6,130.8,133.1,141.5$, 149.0, 167.1; IR $v 3050,2920,1715,1660,1440,1370,1270,1170,970,750$.

Preparation of E2b. To a solution of aldehyde $5(1.48 \mathrm{~g}, 5.59 \mathrm{mmol})$ in $40 \mathrm{~mL}$ of $\mathrm{CH}_{3} \mathrm{CN}$ was successively added $\mathrm{LiCl}(0.284 \mathrm{~g}, 6.7 \mathrm{mmol})$, dimethylacetylmethyl phosphonate $(0.956 \mathrm{~mL}$, $6.7 \mathrm{mmol})$ and diisopropylethyl amine $(0.976 \mathrm{~mL}, 5.59 \mathrm{mmol})$. The resulting solution was stirred overnight at room temperature. Water was added and the mixture extracted twice with $\mathrm{Et}_{2} \mathrm{O}$. Combined organic phases were washed with brine and dried over $\mathrm{MgSO}_{4}$. Purification by flash chromatography ( $\left.\mathrm{PE} / \mathrm{Et}_{2} \mathrm{O} 8: 2\right)$ led to the methyl ketone E2b as an oil in $82 \%$ yield. ${ }^{1} \mathrm{H}-\mathrm{NMR}$ $\delta$ 2.12-2.40 (9H, m), 2.77-2.85 (2H, m), 5.4-5.6 $(2 \mathrm{H}, \mathrm{m}), 6.08(1 \mathrm{H}, \mathrm{d}, J=16), 6.79(1 \mathrm{H}, \mathrm{dt}, J=$ 6.6, 16), 7.02-7.11 $(1 \mathrm{H}, \mathrm{m}), 7.18-7.28(2 \mathrm{H}, \mathrm{m}), 7.54(1 \mathrm{H}, \mathrm{d}, J=8.3) ;{ }^{13} \mathrm{C}-\mathrm{NMR} \delta 27.3,31.4$, $32.7,33.1,36.6,124.9,127.7,128.0,129.8,130.8,131.9,133.1,141.5,148.1,199.1$.

Preparation of phosphonium salt. 4-bromobutyronitrile( $6.7 \mathrm{~mL}, 67.5 \mathrm{mmol})$ and triphenylphosphine $(17.7 \mathrm{~g}, 67.5 \mathrm{mmol})$ were dissolved in toluene $(150 \mathrm{~mL})$. The resulting solution was stirred at reflux for 2 days. A white precipitate appeared during the reaction and was filtered and washed with $\mathrm{Et}_{2} \mathrm{O}$. The phosphonium salt was dried under vacuum to give $13.7 \mathrm{~g}, 49 \%$ yield .

Preparation of 6. KHMDS ( $4 \mathrm{~g}, 20 \mathrm{mmol})$ and the phosphonium salt $(8.2 \mathrm{~g}, 20 \mathrm{mmol})$ are dissolved in anhydrous THF $(100 \mathrm{ml})$ at $0^{\circ} \mathrm{C}$. The mixture was stirred for 15 minutes and then the aldehyde 3 ( $2.13 \mathrm{~g}, 10 \mathrm{mmol})$ in $20 \mathrm{~mL}$ of THF is added dropwise to the solution of the ylide. After 2 hours at $0^{\circ} \mathrm{C}$, the mixture was pourred in petroleum ether $(200 \mathrm{~mL})$ to precipitate triphenylphosphine oxide. The solution was filtered through a pad of silica gel, evaporated and purified by flash chromatography ( $\left.\mathrm{PE} / \mathrm{Et}_{2} \mathrm{O} 9: 1\right)$ to afford nitrile 6 in $90 \%$ yield as a pale yellow oil. ${ }^{1} \mathrm{H}-\mathrm{NMR} \delta$ 2.15-2.45 $(6 \mathrm{H}, \mathrm{m}), 2.82(2 \mathrm{H}, \mathrm{t}, J=7.5), 5.35-5.48(1 \mathrm{H}, \mathrm{m}), 5.58-5.70(1 \mathrm{H}, \mathrm{m})$, 7.03-7.11 $(1 \mathrm{H}, \mathrm{m}), 7.16-7.29(2 \mathrm{H}, \mathrm{m}), 7.56(1 \mathrm{H}, \mathrm{dt}, J=8.5,1) ;{ }^{13} \mathrm{C}-\mathrm{NMR} \delta 17.4,23.2,27.6$, $35.9,119.3,127.4,127.8,124.4,126.3,130.8,131.8,132.9,140.7$; IR $v 3060,3010,2920,2860$, 2240, 1565, 1470, 1440, 1025, 750 .

Preparation of 7. Nitrile 6 (1.17 g, $4.44 \mathrm{mmol})$ was dissolved in $50 \mathrm{~mL}$ of $\mathrm{Et}_{2} \mathrm{O}$. The solution was cooled down to $-78^{\circ} \mathrm{C}$ and then DIBAL-H (1M in hexane, $8.9 \mathrm{mmol}$ ) was added dropwise. The resulting mixture was stirred at this temperature for 30 minutes and warmed up to RT for 4 hours. The reaction was quenched at $0^{\circ} \mathrm{C}$ with methanol and a solution of sodium and potassium tartrate $(0.7 \mathrm{M})$. The medium was extracted with $\mathrm{Et}_{2} \mathrm{O}(2 \times 50 \mathrm{~mL})$ and the solvent removed under vacuum. The crude oil was purified by flash chromatography $\left(\mathrm{PE} / \mathrm{Et}_{2} \mathrm{O} 4: 1\right)$ to afford aldehyde 7 in $90 \%$ yield as a pale yellow oil. ${ }^{1} \mathrm{H}-\mathrm{NMR} \delta 2.34-2.45(6 \mathrm{H}, \mathrm{m}), 2.80(2 \mathrm{H}, \mathrm{t}, J=7.5)$, 5.35-5.48 $(1 \mathrm{H}, \mathrm{m}), 5.58-5.70(1 \mathrm{H}, \mathrm{m}), 7.03-7.11(1 \mathrm{H}, \mathrm{m}), 7.16-7.29(2 \mathrm{H}, \mathrm{m}), 7.56(1 \mathrm{H}, \mathrm{dt}, J=$ 8.5, 1), $9.70(1 \mathrm{H}, \mathrm{s}) ;{ }^{13} \mathrm{C}-\mathrm{NMR} \delta 20.1,27.5,36.0,43.7,124.5,127.4,127.7,128.5,129.8,130.7$, 132.8, 141.0, 202.0; IR v 3060, 3010, 2920, 2720, 1725, 1570, 1470, 1440, 1025, 750. 
Preparation of Z2a.Triethyl phosphonoacetate $(1.06 \mathrm{~mL}, 5.33 \mathrm{mmol})$ was added dropwise to a suspension of $\mathrm{NaH} 60 \%$ in mineral oil $(234 \mathrm{mg}, 5.84 \mathrm{mmol})$ in anhydrous THF $(12 \mathrm{~mL})$ at $0^{\circ} \mathrm{C}$. After 10 minutes, aldehyde $7(1.42 \mathrm{~g}, 5.31 \mathrm{mmol})$ in $3.5 \mathrm{~mL}$ of THF was added dropwise to the previous solution. After 2 hours at $0^{\circ} \mathrm{C}$, the starting material was consumed and the reaction quenched with a saturated $\mathrm{NH}_{4} \mathrm{Cl}$ solution and extracted twice with $\mathrm{Et}_{2} \mathrm{O}$. Combined organic phases were washed with brine dried with $\mathrm{MgSO}_{4}$ and concentrated under vacuum. The crude oil was purified by flash chromatography ( $\left.\mathrm{PE} / \mathrm{Et}_{2} \mathrm{O} 9: 1\right)$ to afford ester $\mathbf{Z 2 a}$ in $80 \%$ yield. ${ }^{1} \mathrm{H}-\mathrm{NMR}$ $\delta 1.28(3 \mathrm{H}, \mathrm{t}, J=7), 2.13-2.16(4 \mathrm{H}, \mathrm{m}), 2.32-2.40(2 \mathrm{H}, \mathrm{m}), 2.78(2 \mathrm{H}, \mathrm{t}, J=7.5), 4.18(2 \mathrm{H}, \mathrm{q}, J=$ 7), 5.34-5.53 (2H, m), $5.80(1 \mathrm{H}, \mathrm{d}, J=15), 6.87-6.97(1 \mathrm{H}, \mathrm{m}), 7.02-7.08(1 \mathrm{H}, \mathrm{m}), 7.17-7.24(2 \mathrm{H}$, m), $7.53(1 \mathrm{H}, \mathrm{d}, J=8) ;{ }^{13} \mathrm{C}-\mathrm{NMR} \delta 14.3,25.7,27.6,32.2,36.1,60.2,121.7,124.5,127.3,127.7$, 129.1, 129.5, 130.6, 132.8, 141.1, 148.5, 166.7; IR v 3050, 2920, 1715, 1660, 1440, 1370, 1270, $1170,970,750$.

Preparation of Z9. Malonitrile (324 mg, $4.45 \mathrm{mmol}$ ), 18-crown-6 (116 mg, $0.44 \mathrm{mmol}$ ), and $t \mathrm{BuOK}$ (549 mg, $4.9 \mathrm{mmol}$ ) were dissolved in $16 \mathrm{ml}$ of THF and stirred for 15 minutes. A solution of Z2a (1.5 g, $4.45 \mathrm{mmol}$ ) in $10 \mathrm{~mL}$ of THF was added via a canula and the resulting mixture was heated at reflux for 3 hours. The reaction was quenched with saturated $\mathrm{NH}_{4} \mathrm{Cl}$ $(20 \mathrm{~mL})$ and extracted with $\mathrm{Et}_{2} \mathrm{O}(3 \times 20 \mathrm{~mL})$. The organic layer was washed with brine, dried with $\mathrm{MgSO}_{4}$ and evaporated under vacuum. The crude oil was purified by flash chromatography $\left(\mathrm{PE} / \mathrm{Et}_{2} \mathrm{O} 9: 1\right)$ to afford ester $\mathbf{Z 9}$ in $84 \%$ yield. ${ }^{1} \mathrm{H}-\mathrm{NMR} \delta 1.27(3 \mathrm{H}, \mathrm{t}, J=7), 1.44-1.58(1 \mathrm{H}, \mathrm{m})$, 1.65-1.76 (1H, m), 1.96-2.15 (2H, m), 2.32-2.49 (4H, m), 2.56-2.63 (H, m), $2.79(2 \mathrm{H}, \mathrm{t}, J=8)$, $4.17(2 \mathrm{H}, \mathrm{q}, J=7), 4.33(\mathrm{H}, \mathrm{d}, J=5), 5.31-5.39(1 \mathrm{H}, \mathrm{m}), 5.50-5.59(1 \mathrm{H}, \mathrm{m}), 7.04-7.1(1 \mathrm{H}, \mathrm{m})$, 7.17-7.27 (2H, m), $7.53(1 \mathrm{H}, \mathrm{dd}, J=8,1) ;{ }^{13} \mathrm{C}-\mathrm{NMR} \delta 14.5,27.2,24.4,28.0,31.2,34.9,36.4$, $36.8,61.8,112.0,112.4,124.7,128.2,128.5,127.8,130.8,131.1,133.2,141.1,171.2$; IR $v 3100$, 2920, 2860, 2240, 1720, 1560, 1430, 1370, 1020, 750.

Preparation of Z8. The procedure was similar as for $\mathbf{Z 9}$ except that we used $\mathrm{NaH}$ ( 2 eq.) instead of $t \mathrm{BuOK}$ and 2 equiv. of dimethylmalonate. The expected product was obtained after 20 hours at reflux. The residue was purified by flash chromatography ( $\left.\mathrm{PE} / \mathrm{Et}_{2} \mathrm{O} 8: 2\right)$ giving $\mathbf{Z 8}$ as an oil in $80 \%$ yield. ${ }^{1} \mathrm{H}-\mathrm{NMR} \delta 1.23(3 \mathrm{H}, \mathrm{t}, J=7), 1.25(6 \mathrm{H}, \mathrm{t}, J=7), 1.43-1.51(2 \mathrm{H}, \mathrm{m}), 2.00-2.07(2 \mathrm{H}$, $\mathrm{m}), 2.27-2.53(4 \mathrm{H}, \mathrm{m}), 2.57-2.64(1 \mathrm{H}, \mathrm{m}), 2.76(2 \mathrm{H}, \mathrm{t}, J=7), 3.57(1 \mathrm{H}, \mathrm{d}, J=6), 4.11(2 \mathrm{H}, \mathrm{q}, J=$ 7), $4.18(4 \mathrm{H}, \mathrm{q}, J=7), 5.32-5.49(2 \mathrm{H}, \mathrm{m}), 7.01-7.08(1 \mathrm{H}, \mathrm{m}), 7.19-7.24(2 \mathrm{H}, \mathrm{m}), 7.51(1 \mathrm{H}, \mathrm{d}, J=$ 8); ${ }^{13} \mathrm{C}-\mathrm{NMR} \delta 14.1,14.3,24.6,27.6,31.6,34.6,36.2,54.2,61.3,61.4,61.8,124.5,127.4$, 127.6, 129.0, 129.7, 130.6, 132.8, 141.1, 168.5, 168.7, 172.4; IR v 3060, 2920, 2860, 1720, 1570, 1440, 1370, 1050, 1020, 860, 750.

Preparation of E10. Same procedure as for Z9. Scale $1.48 \mathrm{mmol}$ of E2a. The residue was purified by flash chromatography ( $\left.\mathrm{PE} / \mathrm{Et}_{2} \mathrm{O} 6: 4\right)$ giving $\mathbf{E 1 0}$ as an oil in $80 \%$ yield. ${ }^{1} \mathrm{H}-\mathrm{NMR}$ $\delta 1.33(3 \mathrm{H}, \mathrm{t}, J=7.2), 1.56-1.68(1 \mathrm{H}, \mathrm{m}), 1.73-1.85(1 \mathrm{H}, \mathrm{m}), 2.00-2.22(2 \mathrm{H}, \mathrm{m}), 2.32-2.53(4 \mathrm{H}$, $\mathrm{m}), 2.61-2.68(1 \mathrm{H}, \mathrm{m}), 2.82(2 \mathrm{H}, \mathrm{t}, J=7.6), 4.2(2 \mathrm{H}, \mathrm{q}, J=7.2), 4.39(1 \mathrm{H}, \mathrm{d}, J=4.9), 5.33-5.42$ $(1 \mathrm{H}, \mathrm{m}), 5.52-5.62(1 \mathrm{H}, \mathrm{m}), 7.05-7.10(1 \mathrm{H}, \mathrm{m}), 7.19-7.28(2 \mathrm{H}, \mathrm{m}), 7.56(1 \mathrm{H}, \mathrm{d}, J=8) ;{ }^{13} \mathrm{C}-\mathrm{NMR}$ $\delta 14.5,27.2,29.7,31.1,33.1,34.9,36.3,36.5,61.8,112.1,112.5,124.9,127.8,128.1,128.9$, $130.9,131.8,133.2,141.3,175.3$; IR $v$ 3100, 2920, 2860, 2240, 1720, 1560, 1430, 1370, 1020, 750.

Preparation of E11. Under argon atmosphere, E2b (0.614 g, 2 mmol) was dissolved in acetonitrile. Malonitrile $(0.132 \mathrm{~g}, 2 \mathrm{mmol})$ and subsequently $\mathrm{RuH}_{2}\left(\mathrm{PPh}_{3}\right)_{4}(0.115 \mathrm{~g}, 0.1 \mathrm{mmol})$ 
were added. The mixture was stirred at $45^{\circ} \mathrm{C}$ for 20 hours. The solvent was removed under vacuum and the residue purified by flash chromatography $\left(\mathrm{PE} / \mathrm{Et}_{2} \mathrm{O}\right.$ 6:4) giving the desired adduct in $63 \%$ yield along with $25 \%$ of unreacted starting material. ${ }^{1} \mathrm{H}-\mathrm{NMR} \delta 1.52-1.80(2 \mathrm{H}$, $\mathrm{m}), 1.96-2.17(2 \mathrm{H}, \mathrm{m}), 2.21(3 \mathrm{H}, \mathrm{s}), 2.29-2.37(2 \mathrm{H}, \mathrm{m}), 2.44-2.51(1 \mathrm{H}, \mathrm{m}), 2.57-2.82(4 \mathrm{H}, \mathrm{m})$, $4.31(1 \mathrm{H}, \mathrm{d}, J=4.7), 5.31-5.40(1 \mathrm{H}, \mathrm{m}), 5.49-5.59(1 \mathrm{H}, \mathrm{m}), 7.03-7.08(1 \mathrm{H}, \mathrm{m}), 7.17-7.24(2 \mathrm{H}$, m), $7.52(1 \mathrm{H}, \mathrm{dd}, J=8,1.1) ;{ }^{13} \mathrm{C}-\mathrm{NMR} \delta 28.3,28.7,29.1,31.5,32.3,32.7,34.6,50.9,108.8$, 109.6, 120.6, 125.0, 125.2, 129.1, 129.2, 130.6, 131.8, 140.9, 204.8 .

Protection of the ketone function in E11. Methyl ketone E11 (642 mg, $1.72 \mathrm{mmol})$ was treated with ethylene glycol (320 mg, $5.16 \mathrm{mmol})$, $p$-toluene sulfonic acid $(33 \mathrm{mg}, 0.17 \mathrm{mmol})$ in $5 \mathrm{~mL}$ of benzene at reflux in a Dean-Stark apparatus for 3 hours. After filtration of the catalyst and evaporation, the crude oil was purified by flash chromatography ( $\mathrm{PE} / \mathrm{Et}_{2} \mathrm{O}$ 7:3) giving the protected ketone in 84\% yield. ${ }^{1} \mathrm{H}-\mathrm{NMR} \delta 1.32(3 \mathrm{H}, \mathrm{s}), 1.57-1.66(1 \mathrm{H}, \mathrm{m}), 1.73-1.87(2 \mathrm{H}, \mathrm{m})$, $1.96(1 \mathrm{H}, \mathrm{dd}, J=2.5,15.3), 2.00-2.13(1 \mathrm{H}, \mathrm{m}), 2.17-2.26(2 \mathrm{H}, \mathrm{m}), 2.35(2 \mathrm{H}, \mathrm{dd}, J=7,15), 2.80$ $(2 \mathrm{H}, \mathrm{dd}, J=7,9.4), 4.00(4 \mathrm{H}, \mathrm{s}), 4.58(1 \mathrm{H}, \mathrm{d}, J=3.6), 5.38-5.47(1 \mathrm{H}, \mathrm{m}), 5.54-5.63(1 \mathrm{H}, \mathrm{m})$, 7.05-7.10 (1H, m), 7.22-7.28 (2H, m), $7.54(1 \mathrm{H}, \mathrm{d}, J=8.1) ;{ }^{13} \mathrm{C}-\mathrm{NMR} \delta 23.9,27.6,29.5,31.8$, $32.7,35.4,36.2$, 38.8, 64.4, 64.9, 109.2, 112.1, 113.3, 124.5, 127.4, 127.7, 128.9, 130.5, 131.2, $132.8,141.1$.

\section{Cyclisation of adducts-general procedure}

On one hand, $\mathrm{Pd}(\mathrm{OAc})_{2}(6 \mathrm{mg}, 0.025 \mathrm{mmol})$, dppe $(20 \mathrm{mg}, 0.05 \mathrm{mmol})$ and heptene $(7 \mu \mathrm{l}$, $0.05 \mathrm{mmol}$ ) were dissolved in $2 \mathrm{~mL}$ of NMP and stirred at $50^{\circ} \mathrm{C}$ until the solution turned red. On the other hand, Z9 (200 mg, $0.496 \mathrm{mmol}), \mathrm{KH}(22 \mathrm{mg}, 0.55 \mathrm{mmol})$ and 18-crown-6 (13 mg, $0.05 \mathrm{mmol}$ ) were dissolved in $2 \mathrm{~mL}$ of NMP and stirred until the termination of gas evolution. Then palladium solution was added to the enolate solution and the mixture stirred at $75^{\circ} \mathrm{C}$ for 3 $\mathrm{h}$. The reaction was quenched with a few drops of $1 \mathrm{M} \mathrm{HCl}$ solution and extracted with $\mathrm{Et}_{2} \mathrm{O}$. The organic layer was washed with brine, dried over $\mathrm{MgSO}_{4}$ and concentrated under reduced pressure. The crude oil was purified flash chromatography ( $\left.\mathrm{PE} / \mathrm{Et}_{2} \mathrm{O} 9: 1\right)$ to afford a mixture of 2 diastereomers 12a and 12b (2/1 ratio) in 73\% yield; mp 126-128 ${ }^{\circ} \mathrm{C}$; ${ }^{1} \mathrm{H}-\mathrm{NMR}$ (major diastereomer) $\delta 1.30(3 \mathrm{H}, \mathrm{t}, J=7), 1.50-1.72\left(\mathrm{H}_{3}, \mathrm{H}_{4}, \mathrm{~m}\right), 1.85-1.93\left(\mathrm{H}_{4}, \mathrm{~m}\right), 1.97-2.11\left(\mathrm{H}_{3}, \mathrm{H}_{13}\right.$, m), 2.14-2.24 ( $\left.\mathrm{H}_{13}, \mathrm{~m}\right), 2.46\left(\mathrm{H}_{15}, \mathrm{~d}, J=15.3\right), 2.49-2.55\left(\mathrm{H}_{2}, \mathrm{~m}\right), 2.66\left(\mathrm{H}_{14}, \mathrm{ddd}, J=12.8,4.6\right.$, 2.7), $2.88\left(\mathrm{H}_{15}\right.$, dd, $\left.J=15.3,2\right), 2.92-3.00\left(\mathrm{H}_{12}, \mathrm{~m}\right), 3.05\left(\mathrm{H}_{12}\right.$, ddd, $\left.J=20,5.8,2\right), 3.14-3.19$ $\left(\mathrm{H}_{5}, \mathrm{~m}\right), 4.20(2 \mathrm{H}, \mathrm{q}, J=7), 7.13-7.20(4 \mathrm{H}, \mathrm{m}) ;{ }^{13} \mathrm{C}-\mathrm{NMR} \delta 14.2,19.9,28.1,29.2,30.1,35.0$, $36.6,37.9,41.9,43.7,61.3,114.1,114.8,126.4,126.8,129.0,129.1,134.1,138.4,170.5$; IR $v$ 3020, 2980, 2940, 2860, 2220, 1730, 1450, 1380, 1270, 1200, 1010, 770, 750; Anal. Calcd. For $\mathrm{C}_{20} \mathrm{H}_{22} \mathrm{~N}_{2} \mathrm{O}_{2}$ : C, 74.50; H, 6.88; N, 8.69. Found $\mathrm{C}, 74.64 ; \mathrm{H}, 6.92 ; \mathrm{N}, 8.53$.

Cyclisation of Z8. The procedure is similar to that previously described. The expected product was obtained, after 2 hours at $75^{\circ} \mathrm{C}$, in $72 \%$ yield as a mixture of 2 diastereomers $\mathbf{1 3}$ a and 13b (1/1). ${ }^{1} \mathrm{H}-\mathrm{NMR} \delta 1.22-1.32(9 \mathrm{H}, \mathrm{m}), 1.45-1.54(1 \mathrm{H}, \mathrm{m}), 1.57-2.10(5 \mathrm{H}, \mathrm{m}), 2.56-2.67(2 \mathrm{H}, \mathrm{m})$, 2.74-2.98 (3H, m), 3.05-3.13 (1H, m), 3.74-3.79 (1H, m), 4.06-4.35 (6H, m), 7.15 (3H, br s), $7.33(1 \mathrm{H}, \mathrm{d}, \mathrm{J}=8) ;{ }^{13} \mathrm{C}-\mathrm{NMR} \delta 14.4,14.6,22.7,26.1,29.3,32.6,36.4,44.1,44.2,45.7,60.7$, $61.5,61.6,124.2,124.6,126.6,126.8,143.7,147.4,170.3,171.8,173.4$; IR v 3060, 2920, 2860, 1760, 1460, 1370, 1260, 1100, 1060, 910, 740; MS/EI : 57 (30), 117 (50, indenyl radical), 210 
(100), 282 (27), 324 (32), 370 (44), 416 (20); Anal. Calcd. For $\mathrm{C}_{24} \mathrm{H}_{32} \mathrm{O}_{6}$ : C, 69.20; H, 7.74. Found C, 68.98; H, 8.01.

Cyclisation of E10. The procedure is similar to that previously described. The expected product 14a was obtained, after 3.5 hours at $75^{\circ} \mathrm{C}$, in $82 \%$ yield as a sole diastereomer: $\mathrm{mp} 88-90{ }^{\circ} \mathrm{C}$; ${ }^{1} \mathrm{H}$ NMR $\left(\mathrm{C}_{6} \mathrm{D}_{6}\right) \delta 0.81(1 \mathrm{H}, \mathrm{ddd}, J=25.4,13.1,3.5), 1.07(3 \mathrm{H}, \mathrm{t}, \mathrm{J}=7), 1.20-1.28(1 \mathrm{H}, \mathrm{m}), 1.25$ (1H, td, $J=12,2.6), 1.62$ (1H, ddd, $J=23.5,12,7), 1.86-1.90(1 \mathrm{H}, \mathrm{m}), 1.94-1.97(1 \mathrm{H}, \mathrm{m}), 2.05-$ $2.09(1 \mathrm{H}, \mathrm{m}), 2.31-2.52(4 \mathrm{H}, \mathrm{m}), 2.90(1 \mathrm{H}, \mathrm{dd}, J=15.8,2.8), 4.03(2 \mathrm{H}, \mathrm{q}, \mathrm{J}=7), 6.90-6.96(2 \mathrm{H}$, m), 7.11-7.13 (2H, m); ${ }^{13} \mathrm{C}-\mathrm{NMR} \delta 14.6,26.9,28.6,29.5,29.7,38.3,38.9,41.9,45.5,47.2,61.6$, $112.9,115.7,126.2,126.8,127.1,129.5,135.7,136.9$, 170.8; IR v 3020, 2980, 2940, 2220, 1730, 1450, 1270, 1010.

Cyclisation of E11 (protected ketone). The procedure is similar to that previously described. The expected product was obtained, after 2.5 hours at $75^{\circ} \mathrm{C}$, in $87 \%$ yield as a mixture of two diastereomers (3/1). The major diastereomer crystallized from diethyl ether and was easily separated: $\mathrm{mp} 184-186^{\circ} \mathrm{C},{ }^{1} \mathrm{H}-\mathrm{NMR} \delta 1.28-1.40(1 \mathrm{H}, \mathrm{m}), 1.40(3 \mathrm{H}, \mathrm{s}), 1.52-1.65(1 \mathrm{H}, \mathrm{m}), 1.88$ 1.99 (3H, m), 2.14-2.27 (2H, m), 2.32-2.55 (3H, m), 2.75-2.81 (1H, m), $3.00(2 \mathrm{H}$, br s), 3.98 (4H, br s), 7.1-7.27 (4H, m); ${ }^{13} \mathrm{C}-\mathrm{NMR} \delta 24.7 .27 .0,29.6,29.9,30.1,38.9,41.6,42.5,47.0,47.4$, $64.8,65.1,109.3,113.4,116.4,126.2,126.7,127.0,129.5,135.8,137.2$; IR v 2990, 2948, 2244, 1490, 1379, 1262, 1038, 753.

Deprotection of the ketone, preparation of 15a (major diastereomer). Protected ketone $(116 \mathrm{mg}, 0.345 \mathrm{mmol})$ was treated by a catalytic amount of $p$-toluene sulfonic acid $(5 \mathrm{mg}) \mathrm{in}$ $5 \mathrm{~mL}$ of acetone at $50{ }^{\circ} \mathrm{C}$. The mixture was stirred for $15 \mathrm{~h}$. and then acid was removed by filtration and the solution evaporated in vacuum. The crude oil was purified flash chromatography $\left(\mathrm{PE} / \mathrm{Et}_{2} \mathrm{O} 7: 3\right)$ to afford 15a in 95\% yield. ${ }^{1} \mathrm{H}-\mathrm{NMR} \delta 1.36-1.53(2 \mathrm{H}, \mathrm{m}), 1.88$ $2.03(2 \mathrm{H}, \mathrm{m}), 2.17-2.26(1 \mathrm{H}, \mathrm{m}), 2.28(3 \mathrm{H}, \mathrm{s}), 2.30-2.38(1 \mathrm{H}, \mathrm{m}), 2.52-2.67(2 \mathrm{H}, \mathrm{m}), 2.72-2.85$ $(2 \mathrm{H}, \mathrm{m}), 2.99-3.05(3 \mathrm{H}, \mathrm{m}), 7.12-7.30(4 \mathrm{H}, \mathrm{m}) ;{ }^{13} \mathrm{C}-\mathrm{NMR} \delta 26.8,28.5,29.3,29.5,30.8,38.8$, 40.3, 45.4, 46.7, 46.9, 113.0, 115.7, 126.0, 126.6, 126.9, 129.3, 135.5, 136.7, 204.7.

Preparation of 16. 12a $(70 \mathrm{mg}, 0.217 \mathrm{mmol})$, was dissolved in a mixture of $1 \mathrm{~mL}$ of $\mathrm{CHCl}_{3}$ and $1 \mathrm{~mL}$ of EtOH at $0^{\circ} \mathrm{C} .4 \mathrm{~mL}$ of $\mathrm{H}_{2} \mathrm{SO}_{4} 75 \%$ were added slowly at $0^{\circ} \mathrm{C}$ to the previous solution, and the resulting mixture was stirred at $\mathrm{rt}$ for 5 days; The reaction was quenched with saturated solution of $\mathrm{NaHCO}_{3}$ and extracted with $20 \mathrm{~mL}$ of $\mathrm{Et}_{2} \mathrm{O}$. The organic layer was washed with water, dried over $\mathrm{MgSO}_{4}$ and concentrated under vacuum. 16 was obtained in $60 \%$ yield as a mixture of two diastereomers 2/1. ${ }^{1} \mathrm{H}-\mathrm{NMR}(\mathrm{DMSO}) \delta 1.22-1.36(1 \mathrm{H}, \mathrm{m}), 1.44-1.59(2 \mathrm{H}, \mathrm{m})$, 1.63-1.69 (1H, m), 1.7-1.88 (2H, m), 2.22-2.30 (1H, m, major), 2.39 (1H, dd, major, J = 18, 4.8), 2.43-2.52 (1H, m), 2.75-2.90 (3H, m), $3.21(1 \mathrm{H}, \mathrm{dd}$, minor, $\mathrm{J}=17.6,4.8), 3.35(1 \mathrm{H}$, dd, major, $\mathrm{J}$ = 18, 13.6), 6.89 (4H, br s, minor), 7.07 (4H, br s, major), 7.33 (s, NH amide, major), 7.45 (s, $\mathrm{NH}$ amide, minor), 10.89 (s, NH imide, major), 11.02 (s, NH imide, minor); ${ }^{13} \mathrm{C}-\mathrm{NMR}$ major $\delta$ $129.9,30.0,30.5,31.3,31.7,36.6,38.1,39.9,57.4,126.4,126.6,129.5,129.6,135.9$, 142.2, 171.2, 173.7, 173.8; ${ }^{13} \mathrm{C}-\mathrm{NMR}$ major $\delta 19.4,27.9,29.2,30.0,31.0,37.4,38.3,39.9,58.8,126.5$, $126.7,129.4,129.7,135.7,141.5,169.9,173.1,173.6$; IR $v 3440,3330,2920,2850,1700,1685$, $1655,1260,1225,765,735 ; \mathrm{MS} / \mathrm{CI}: \mathrm{M}-\mathrm{H}^{+}=313$. 


\section{References and notes}

1. (a) Negishi, E.I. Pure \& Appl. Chem. 1992, 64, 323. (b) Overman, L.E.; Abelman, M.M.; Kucera, D.J.; Tran, V.D.; Ricca, D.J. Pure \& Appl. Chem. 1992, 64, 1813. (c) Hok, T.L. Tandem Organic Reactions; Wiley Interscience: New York, 1992. (d) Tietze, L.F.; Beifuss, U. Angew. Chem., Int. Ed. 1993, 32, 131. (e) Tsuji, J. Palladium Reagents and Catalysts; Innovations in Organic Chemistry; Wiley: Chischester, 1995. Tetrahedron Symposium-inprint 1996, 52, Vol.35. (f) Bräse, S. In Metal-Catalyzed Cross-coupling Reactions, Diederich, F.; Stang, P.J. Eds; Wiley-VCH: Weinheim, 1998, pp 99-166.

2. Bouyssi, D.; Balme, G.; Fournet, G.; Monteiro, N.; Goré, J. Tetrahedron Lett. 1991, 32, 1641.

3. (a) Balme, G.; Bouyssi, D. Tetrahedron Symposium in Print 1994, 50, 403. (b) Coudanne, I.; Balme, G. Synlett 1998, 998.

4. (a) Bruyère, D.; Gaignard, G.; Bouyssi, D.; Balme, G. Lancelin, J-M. Tetrahedron Lett. 1997, 38, 827. (b) Bruyère, D., Bouyssi, D.; Balme, G. to be submitted

5. (a) Grossman, R.B.; Rasne, R.M.; Patrick, B.O. J. Org. Chem. 1999, 64, 340. (b) Grossman, R.B.; Pendharkar, D.S.; Rasne, R.M.; Varner, M.A. J. Org. Chem. 2000, 65, 3255.

6. (a) Wolfe, J.P.; Rennels, R.A.; Buchwald, S.L. Tetrahedron 1996, 52, 7525. (b) Pattenden, G.; Wiedenau, P. Tetrahedron Lett. 1997, 38, 3647.

7. Nagaoka, H.; Iwashima, M.; Abe, H.; Yamada, Y. Tetrahedron Lett. 1989, 30, 5911.

8. Raker, J. J. Heterocycl. Chem. 1966, 3, 319.

9. Blanchette, M.A.; Choy, W.; Davis, J.T. ; Essenfeld, A.P. ; Masamune, S. ; Roush, W.R.; Sakai, T. Tetrahedron Lett. 1984, 2, 2183

10. A similar tandem Michael addition / copper mediated cyclisation reaction has been recently reported by our group see Bouyssi, D.; Monteiro, N.; Balme, G. Tetrahedron Lett. 1999, 40, 1297.

11. Gomez-Bengoa, E.; Cuerva, J.M.; Mateo, C.; Echavarren, A.M. J. Am. Chem. Soc. 1996, $118,8553$.

12. The difference in the rate of cyclisation between a malononitrile and a malonate derivative was observed previously, see: Bouyssi, D.; Coudanne, I.; Uriot, H.; Gore, J.; Balme, G. Tetrahedron Lett. 1995, 38, 8019. 